\title{
Socialization of Values Through "Strategic Poles”
}

\author{
Hector Zazueta Beltrán, Nora Teresa Millán Lopez, Rafael Castro Pérez \\ Autonomous University of Sinaloa, Culiacán, México
}

\begin{abstract}
Two groups of second grade from a senior high school that is part of The Autonomous University of Sinaloa in Mexico ( $N 1=47$ and $N 2=46$ ) were selected. Each group was divided by gender. The "average score” was measured as an indicator of academic achievement, before and after the intervention. In one of the groups, an intervention called "Socialization of Values Through Strategic Poles” was performed, while in the other group there was not intervention. The six students with highest academic achievement were trained about the importance of practicing life values such as respect, honesty, responsibility, self-discipline, solidarity and tolerance, as important aspects of being a good person and developing their human potential. These values were chosen according to the Association for Living Values Education International (ALIVE); the values were discussed within the classroom where the students ranked them. Groups called "Strategic Poles to Socialize Values" were formed with the expectation that students with higher academic achievement influenced the students with lower achievement, so the latter could improve their academic performance. From the comparative study, the results showed that the group which received the intervention had higher achievement than the group that received no intervention. Women in the group that received intervention performed better than men of the same group. The performance of the research through intervention allowed us to observe its usefulness and to propose it as a viable option to promote values in today’s society, both in business and school.
\end{abstract}

Keywords: values, socialization, strategic poles, academic achievement

\section{Project Background}

Culiacan, the capital of Sinaloa, is located in Northwestern Mexico, and is a city with social, economic, and political importance in the area. In this city, some researchers have showed that in Sinaloa, the high school students are in constant psychological conflict when they have to decide what to do with their life, because they frequently receive inconsistent messages of morality. On one side, society says: "Go ahead, study and prepare yourself for progress and to be a good citizen", while on the other side, there is a voice (sometimes the same) that whispers: "Studying is worth little, the important thing is to have possessions so society will respect you, to be recognized and welcome anywhere” (Zazueta \& Pardini, 2011).

According to Zazueta and Pardini (2011), these young people are cohabiting in a society where, through

Hector Zazueta Beltrán, Doctorate in Business Studies, professor and researcher at the School of Administration and Accounting, Autonomous University of Sinaloa.

Nora Teresa Millán Lopez, Doctorate in Social Sciences, professor and researcher at the School of Economics and Social Sciences, Autonomous University of Sinaloa.

Rafael Castro Pérez, Doctorate in Existential Psychotherapy, professor and researcher at the School of Psychology, Autonomous University of Sinaloa.

Correspondence concerning this article should be addressed to Hector Zazueta Beltrán, School of Administration and Accounting, Autonomous University of Sinaloa, Mexico. E-mail: Hzeta28@hotmail.com. 
the excessive use of the media, they are pressured to set their values. The perception that high school students have the options that the society in which they live offers in order to have a better social status, is accepted and acknowledged by people. It is an important factor in explaining why students in Sinaloa are losing interest in being educated; ergo, education is losing value because it is losing importance.

\section{Values}

Value concept is "an enduring belief that a specific mode of conduct or end-state of existence is personally or socially preferable to an opposite or converse mode of conduct or end-state of existence” (Rokeach, 1973).

Additionally values are solid beliefs, usually expressed by antagonistic pairs of words, which by individually preferred choice rule as guidelines of individuals and groups behaviors; they are hierarchically ordered depending on the context, the individuals' current situation and they are ranked from very important to not important (Zazueta \& Arciniega, 2010).

On the other hand, values are preferred habits of an individual, a couple, a group, or society (Lafarga, 2013).

From the three above definitions, it can be seen that values are a matter of individual choice preference according to the importance that the decision has in its current context, although it should be noted that this choice is not exempt from conflicts and sometimes is not as free, but still remains as a choice.

\section{Socialization}

According to the Royal Spanish Academy (RSA, Retrieved from http://www.rae.es), socialization is promoting social conditions that, regardless of the relationship with the State, stimulate among human beings a personal integral development.

Socialization is essential to promote values within organizations (Chatman, 1989) and suggests that individuals learn and apprehend values depending on the interaction they have with other individuals. This is observable in daily life when people make personal relationships by socializing mostly with people that resemble them (Rokeach, 1973). The similarity of values produces a social system or culture that facilitates the interactions necessary for individuals to achieve their common goals (Kluckhohn, 1951).

\section{Strategic Poles}

The same Royal Spanish Academy, among various concepts, defines a pole as a center of attention or interest.

Therefore, merging these two concepts originates the term of Strategic Poles that for the purpose of this research will be defined as an intentionally formed group of five or six students. One of the students with a minimum academic score of 80 percent and the rest with lower scores, the integration of these groups intends to prove that students with highest academic scores influence their peers to increase their academic scores, through a methodology of intervention.

\section{Values in the School Environment}

In a society where there are no clear formulated options of values, Allport (1924) said that is an "anomic" society.

The fact that a society has an ethical system can be recognized by their possession of a mental construct of values expressed as principles to be used and interpreted in order to guide social behavior (i.e., the one that has a meaning and relevance to others) and to judge as good or bad. Hence, societies require that direction and values serve as elements that unite social behavior (Singer, 1995). 
In the school environment, it is noticeable that being educated has a low value, despite the efforts of a few teachers to motivate their students. It is very common for most of the school's speeches about their own educational philosophies, ideologies, and principles to hear eloquent dissertations on unobjectionable values and sometimes sublime contents in the institutional documentation, but all that is absent in everyday classrooms practice, offices, and especially in the interpersonal relationships between teachers and students, between managers and employees, and between individuals and groups at all levels (Lafarga, 2013).

A lesson about values does not greatly influence the behavior of those who take them, if those values are not observed in the practice, in this case by the educator. He considers it necessary to rethink the education system and suggests one that includes feelings, emotions, attitudes, and values based on respect and transparency (Lafarga, 2013).

Education in values has been foisted on the family and it may be true that parents ought to care what kind of values are practiced by their children, but from the social point of view, this is a subject that matters and is interesting to other institutions. Family is the social entity with the right and obligation to develop individual values, but the development of values also is a responsibility of the school and this is not something that happens in its fullness as a natural result of the evolutionary process of the human being. Values must be explicitly and systematically pursued. According to the same author, the school cannot take responsibility for the development of values in the students, so educational institutions should strengthen links with socializing agencies from the community with which it is possible to do so; this requires breaking with the classic style to operate, both the school and classroom (Schmelkes, 1996).

School is considered as a social entity that has the opportunity to "fill" its students with values (Zazueta \& Pardini, 2011) and values are acquired through socialization (Chatman, 1989). The individual, who obtains an academic degree in Mexico, socialized at school at least 25 hours a week for 19 years during school season.

However, it seems that in several Latin American countries', having a college degree is not an enough motivation for the students who want to have a higher social status. Perhaps, because obtaining the document is just a final goal for those studying; students forget the learning that offers the process to get a degree. For this type of Latin American and perhaps global society, some authors suggest insistently to retake the study of values if teachers want to have an influence in a society with different behaviors (Fabelo, 2003).

In Culiacan, Sinaloa, Mexico, and other Mexican cities threatened by violence, the general outcry is that people want a better life: a more peaceful coexistence with healthier values. But authors suggest that, a better life will not ever be possible if people do not turn inward and consciously look at the interior cavities of our mind and soul in order to define the values that people want to live every day (Frankl, 2004).

Given the above, the authors of this research decided to select a group of high school sophomores and pay special attention to the formation of values. It is no longer enough to talk about values in the school, therefore it is necessary to permanently implement the practices of values, as it is already happening in some universities around the globe, such as the University of Washington (Retrieved from http://www.phil.washington .edu/POV/).

\section{General Objective}

Perform an applied research through group intervention; our method is called "Socialization of Values Through Strategic Poles" where two groups of high school students will be chosen, one would be intervened and the other group would not, at the end comparisons were made with the purpose to observe the possible effects from the intervention. 


\section{Hypothesis}

H1: The average scores of the group that had intervention shall increase in greater proportion than the group that did not.

H2: The mean of the average scores of women from the group that had intervention shall be greater than the mean of the average scores of the women that did not.

H3: The average scores of men shall be greater after intervention.

H4: The average scores of women shall be greater after intervention.

\section{Methodology}

Participatory research was used as assessment method and approach was quantitative: Research and action were selected by the researchers, with the participation of the subjects investigated. The ultimate goal of this research was to look for changes in the community to improve their average score as a consequence of actions selected by researchers through the intervention named "Socialization of Values Through Strategic Poles".

In order to conduct a comparative study, researchers selected two groups of second grade from a Senior High School (between 16 and 17 years old) that is part of the Autonomous University of Sinaloa, integrated with students mainly from middle class. In both groups, the gender variable was considered to be observed and the variable "average score" was measured before and after the intervention. Only one of the groups was under the intervention "Socialization of Values Through Strategic Poles". The goal was to compare the group that had intervention ( $n=47$ students) with the group that did not receive intervention ( $n=46$ students) and to observe the possible effects of the trends over time, analyzing the means of the variable "average score".

The group that was under the intervention "Socialization of Values Through Strategic Poles" was in a classroom called "Classroom With Values". The intervention consisted of choosing students who have the highest academic average and that have not failed any subject, the result: six students. Then, these students were placed in five groups called strategic poles to socialize values with other students with lower academic achievements and a greater number of subjects failed. Four groups were located in each corner of the classroom; the fifth group was located at the center of the classroom.

In order to perform the intervention, it was necessary to train the six chosen students about the importance of practicing life values such as respect, honesty, responsibility, self-discipline, solidarity, and tolerance as important aspects to be a good person and to develop human potential. These values were chosen according to the Association for Living Values Education International (ALIVE) (Retrieved from http://www.livingvalues.net/) and were discussed in the classroom where the students themselves ranked the values following the methodology suggested by Mindtech (Retrieved from http://www.mindtech3.com/services/values_overview.html).

The responsible of this project was a full time teacher of the group and he spent one hour a week talking to the group about the importance of such values. The period of intervention lasted 60 hours in total, distributed in 60 weeks, approximately. It was expected that the students with higher academic achievement had an influence in their groups so the students with lower academic achievement would embrace these values and make them part of their behavior at the school and consequently increase their average scores.

Prior to the intervention, at the beginning of the first semester of the school year, in a list drawn from both groups, the average scores of the students were recorded with information from their transcripts issued by the Department of Academic Records. At the end of the intervention (end of the second semester), the final grades 
were recorded in the same transcripts to observe and compare the average scores of both groups under observation.

\section{Implementation of "A Classroom With Values”}

In order to perform the research-intervention known as "Socialization of Values Through Strategic Poles", it was necessary to determine which one would be the "Classroom With Values". The intervention was gradually implemented during a full school year and it was developed with a program that was designed by adapting a work made in the United States of America in 2002 (Retrieved from http://www.coachingjourneys.com/pdf/truvalues.pdf). The intervention was divided into the following stages:

Stage I: identification of the individual and its closest social pole.

Stage II: identification and promotion of the desired values to build the conceived social context.

Stage III: approach goals and plans, both personal and group, to actuate the established values.

Stage IV: perform axiological audits to verify compliance of goals and plans, both personal and group.

Stage V: acknowledge the culmination of the project "Classroom With Values".

\section{Findings}

In order to perform the study, our two samples were: two groups of sophomores from one of the campus at the University Autonomous of Sinaloa's High Schools. In the first group the intervention "Socialization of Values Through Strategic poles" was applied, while in the second group it was not. The intervened group was formed by 22 men (46.8\%) and 25 women (53.2\%), whilst the group that was not intervened was formed by 19 men (41.3\%) and 27 women (58.7\%); the age range of all students was between 16 and 18.

To validate H1, since the variable "average score" is continuous, researchers used the software STATISTICA V 8.0 and applied $T$ tests to the variations in the average scores. The average scores were obtained in august 2011 and 2012 from their transcripts. The samples were $N 1=47$ (students with intervention) and $N 2=46$ (students without intervention).

In Table 1, it is observable that Pvalue $=0.022$ (adjusted to half $=0.43847$, for being a single-tailed test) is smaller than the level of significance that is 0.05 ; this is enough evidence to validate the alternative hypothesis 1: The average scores of the group that had intervention shall increase in greater proportion than the group that did not (See Table 1).

Table 1

Scores Mean for Both Groups in General

\begin{tabular}{|c|c|c|c|c|c|c|c|c|c|c|c|}
\hline \multirow[t]{2}{*}{ Variable } & \multicolumn{11}{|c|}{$\begin{array}{l}\text { T-tests: Grouping } \\
\text { Group } 1: 1 \\
\text { Group } 2: 2 \\
\end{array}$} \\
\hline & Mean 1 & Mean 2 & $t$-value & $d f$ & $P$ & Valid 1 & Valid 2 & Std.Dev 1 & Std.Dev 2 & $\begin{array}{l}F \text {-ratio } \\
\text { Variances }\end{array}$ & $\begin{array}{l}P \\
\text { Variances }\end{array}$ \\
\hline difPROM & 0.139574 & -0.06312 & 2.043969 & 91 & 0.043847 & 47 & 46 & 0.45237 & 0.503099 & 1.236855 & 0.475433 \\
\hline
\end{tabular}

From the analysis of the table above, it is stated that the average scores of the students with intervention increased more than the ones of the group that were not intervened. This can also be observed in the Figure 1 .

To validate H2: The mean of the average scores of women from the group that had intervention shall be greater than the mean of the average scores of the women that did not, researchers applied the Mann Whitney test to the difference between the average scores before and after the intervention to a group of 25 female 
students and also to the group of 27 female students who did not receive the intervention. Since the variable "average scores" is a continuous one, and the deviations from the samples are different, the $T$-test is not applicable; therefore the nonparametric Mann-Whitney test is appropriate.

Table 2 shows that Pvalor $=0.041$ is less than the 0.05 significance level, therefore there is sufficient evidence to accept H2 (See Table 2).

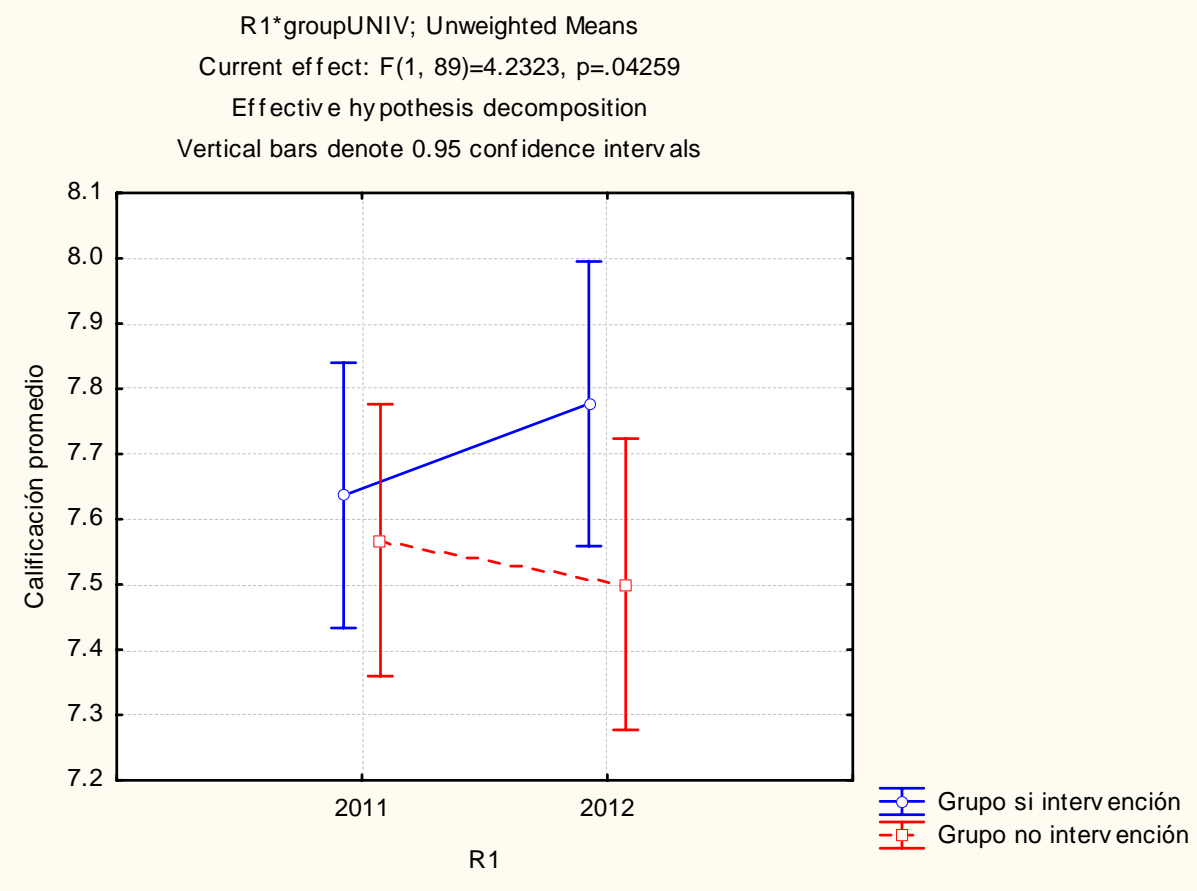

Figure 1. Average scores performance per group.

Table 2

Means of the Average Scores Performed by the Female Students After Receiving the Intervention and for Those Who Did not (Mann-Whitney U Test)

\begin{tabular}{|c|c|c|c|c|c|c|c|c|c|c|}
\hline \multirow[t]{2}{*}{ Variable } & \multicolumn{10}{|c|}{$\begin{array}{l}\text { By variable group UNIV } \\
\text { Marked tests are significant at } p<0.05000 \\
\text { Include condition: Gender }=1\end{array}$} \\
\hline & $\begin{array}{l}\text { Rank Sum } \\
\text { Group } 1\end{array}$ & $\begin{array}{l}\text { Rank Sum } \\
\text { Group } 2\end{array}$ & $U$ & $Z$ & $P$-level & $Z$ adjusted & $P$-level & $\begin{array}{l}\text { Valid } N \\
\text { Group } 1 \\
\end{array}$ & $\begin{array}{l}\text { Valid } N \\
\text { Group } 2 \\
\end{array}$ & $\begin{array}{l}2 * 1 \text { sided } \\
\text { exact } p\end{array}$ \\
\hline difPROM & 636.0000 & 589.0000 & 211.0000 & 1.728665 & 0.041500 & 1.728886 & 0.083831 & 25 & 27 & 0.085731 \\
\hline
\end{tabular}

From the analysis of the table above, researchers state that female students who received the intervention "Socialization of Values Through Strategic Poles" increased their average scores in a higher proportion than the students who did not receive such intervention.

Furthermore to validate H3 that states that the average scores of men shall be greater after intervention , researchers applied the non-parametric Wilcoxon test to a group of male students $(N=22)$ who received the intervention "Socialization of Values Through Strategic Poles" by comparing the means of the average scores in two phases, before and after the intervention.

Table 3 shows that Pvalor $=0.101$ is greater than the 0.05 significance level, therefore there is no sufficient evidence to accept $\mathrm{H} 3$. 
Table 3

Means of the Average Scores of the Male Students Before and After Having the Intervention

\begin{tabular}{lllll}
\hline & \multicolumn{2}{l}{$\begin{array}{l}\text { Wilcoxon Matched Pairs Test } \\
\text { Marked tests are significant at } p<0.05000\end{array}$} \\
& $\begin{array}{l}\text { Include condition: Genero }=1 \text { and group UNIV }=1 \\
\text { Pair of variables }\end{array}$ & $T$ & $Z$ & $P$-level \\
\hline & $N$ & 76.0000 & 1.639515 & 0.101107 \\
\hline prom2011 \& prom2012 & 22 & $T$
\end{tabular}

Finally, to validate H4: The average scores of women shall be greater after intervention, researchers also applied the nonparametric Wilcoxon test to the group of female students $(N=25)$ that received the intervention called "Socialization of Values Through Strategic Poles". The mean of average scores in two phases was compared, before and after the intervention.

Table 4 shows that Pvalor $=0.033$ is less than the 0.05 significance level, therefore this is sufficient evidence to accept $\mathrm{H} 4$ (See Table 4).

Table 4

Mean of the Scores of the Female Student's Group Before and After Intervention

\begin{tabular}{|c|c|c|c|c|}
\hline \multirow[t]{2}{*}{ Pair of Variables } & \multicolumn{4}{|c|}{$\begin{array}{l}\text { Wilcoxon Matched Pairs Test } \\
\text { Marked tests are significant at } p<0.05000 \\
\text { Include condition: Genero }=1 \text { and group UNIV = } 1\end{array}$} \\
\hline & $\begin{array}{l}\text { Valid } \\
N \\
\end{array}$ & $T$ & $\mathrm{Z}$ & $P$-level \\
\hline prom2011 \& prom2012 & 25 & 8.50000 & 2.125646 & 0.033534 \\
\hline
\end{tabular}

\section{Conclusions}

Performing the research through the intervention "Socialization of Values Through Strategic Poles" allowed observing positive aspects about the usefulness of this proposed method to promote values in modern society. As it could be observed from the results, the group that received the intervention showed better results than the group that did not have an intervention. The intervention had a greater impact on women than on men.

It is common to hear comments from teachers and administrators that changing attitudes and behaviors is a challenging task and the authors agree with that; however, with the results of this research, it is evident that if you start with small focus groups, teachers will be contributing with the school's mission to form better citizens. Nonetheless, this task shall be even more difficult without a teaching staff that puts into practice, as some authors say values are inherent in the practice of teaching, such as vocation, professionalism, pedagogical and didactic competencies, as well as a human and ethical education to understand the problems of the group and individual cases (López, 2012). Given this phenomenon, authors of this research believe that discouragement is not an option for those who have a responsibility to educate; on the contrary, teachers must redouble the daily effort to promote values for peaceful coexistence in schools spaces.

\section{Future Lines of Research}

In the future it would be interesting to observe if in a research with students from another socio-economic status, different results could be observed.

According to Zazueta and Pardini (2011), people are in a society where a lot of vain issues are given to us by social pressure and the media, putting aside education as an unimportant asset. According to these authors, 
society should give greater recognition and offer better alternatives to those with a professional degree, going to school should be more than just memorize dates, formulas and acquire skills and competencies, hence the school should emphasize on promoting the values of coexistence that allows to have better students and therefore citizens that are aware of their daily behaviors.

\section{References}

Allport, F. H. (1924). Social psychology. New York: Houghton Mifflin.

Chatman, J. A. (1989). Improving interactional organizational research: A model of person-organization fit. The Academy of Management Review, 14(3), 333-349.

Fabelo, J. R. (2003). Los Valores y sus Desafíos Actuales(Values and modern challenges). Havana, Cuba: Editorial José Martí.

Frankl, V. (2004). El Hombre en Busca de Sentid(Man’s in search of meaning, 8th ed.). Barcelona, Spain: Editorial Herder.

Kluckhohn, C. (1951). Values and value orientations in the theory of action. In T. Parsons, \& E. A. Shils (Eds.), Toward a general theory of action (pp. 388-433), Cambridge, MA: Harvard University Press.

Lafarga, J. (2013). Desarrollo humano: el crecimiento personal(Human development: Personal growth). México City: Editorial Trillas.

Living Values Education. (2012). Retrieved from http://www.livingvalues.net/

López, F. (2012). Pensamiento social sobre profesores universitarios y normalistas en sinaloa(Social Thought about University Professors and the teaching profession in Sinaloa). México: Universidad Autónoma de Sinaloa/Universidad Pedagógica Nacional.

Real Academia Española. (2012). Retrieved from http://www.rae.es

Rokeach, M. (1973). The nature of human values. New York: The Free Press.

Schmelkes, S. (1996). Documentos internacionales de itam: Mexico. Retrieved January 2012, from http://biblioteca.itam.mx/estudios/estudio/letras45-46/texto03/sec_1.html

Singer, P. (1995). Compendio de ética (Internal Documents from ITAM). Retrieved from http://biblioteca.itam.mx/estudios/estudio/letras45-46/texto03/sec_1.html (Accessed on January 2012)

Tru Values Program. (2012). Retrieved from http://www. coachingjourneys.com/pdf/truvalues.pdf

Values in Society. (2012). Retrieved from http://www.phil.washington.edu/POV/

Values Overview. (2012). Retrieved from http://www.mindtech3.com/services/values_overview.html

Zazueta, H. G., \& Arciniega, L. M. (2010). Desarrollo de Valores en el Trabajo(Implementation of values at work). México: Editorial Trillas.

Zazueta, H. G., \& Pardini, J. C. (2011). Values and educative aspirations. Chinese Business Review, 10, 226-232. 